\title{
Factors behind the employment loss in Galicia: Great Recession of 2008 vs. the first wave of the COVID-19 pandemic
}

\author{
Yolanda Pena-Boquete* / Iria Dios-Murcia
}

AYeconomics Research Centre, División de Investigación, Edificio Emprendia, Campus Vida s/n, 15782 Santiago de Compostela, Spain

Received: 29 January 2021 / Accepted: 10 May 2021

\begin{abstract}
In a recession such as COVID-19 pandemic with important consequences in the labour market, it is important to design policies that really address factors behind the employment loss for each demographic subgroup. The aim of this paper is to decompose and identify these factors for each demographic group, comparing the effects of the Great Recession with the COVID-19 pandemic. Although segregation was saving job loss for young and female workers in the Great Recession, these groups were concentrated in the most affected sectors during the COVID-19, increasing their job loss. However, a policy which just focuses on recovering employment from these sectors will not solve the employment problems behind young workers since they are being used as reserved workers fired in the downturn and hired in the upturns. We attempt to measure also the effect of Expediente de Regularización de Empleo Temporal (ERTE) subsidies on employment.
\end{abstract}

\section{Keywords}

Youth employment / Female employment / Business cycle / COVID-19 / Industrial segregation.

\section{Factores detrás da perda de emprego en Galicia: Gran Recesión de 2008 vs. a primeira onda da pandemia COVID-19}

\section{Resumo}

Nunha recesión con importantes consecuencias no mercado laboral, como a causada pola pandemia da COVID-19, é importante deseñar políticas que realmente aborden os factores que hai detrás da perda de emprego. 0 obxectivo deste traballo é descompoñer e identificar estes factores para distintos grupos demográficos en función do seu sexo e idade, comparando os efectos da Gran Recesión cos sufridos na primeira onda da COVID-19. Os resultados mostran que a concentración do emprego xuvenil en determinados sectores, en particular o das mulleres, amorteceu a súa perda de emprego durante a Gran Recesión. Non obstante, estes grupos concentráronse nos sectores máis afectados durante a COVID-19, aumentando a súa perda de emprego. Con todo, unha política que se centre só en recuperar o emprego destes sectores non resolverá os problemas de emprego das persoas traballadoras mozas xa que se estarán a empregar como reserva de traballo, despedidas na recesión e contratadas na recuperación. Finalmente, tentamos medir ata que punto a política dos Expedientes de Regularización de Emprego Temporal (ERTE) salvagardou empregos.

\section{Palabras clave}

Emprego xuvenil / Emprego feminino / Ciclo económico / COVID-19 / Segregación industrial.

JEL Codes: J08, J21.

\footnotetext{
*Y. Pena-Boquete: y.penaboquete@ayeconomics.com (corresponding author), I. Dios-Murcia: iriadiosm@ayeconomics.com We would like to express our gratitude to the Instituto Galego de Estatística (IGE) for facilitating the data used in this paper. We would like to thank Juan Ares and Alberto Meixide as well as two anonymous referees for their comments on this paper, which helped to highly improve this work.
} 


\section{Introduction}

In 2020, the COVID-19 pandemic dramatically damaged the Spanish labour market, especially the service sector. Studies from Arce (2020), Felgueroso et al. (2020) or López Oller (2020) show the important increase in the unemployment rate since the outbreak of the COVID-19 pandemic, despite the Spanish government's extraordinary measures. For instance the Expediente de Regularización de Empleo Temporal (ERTE) subsidies (Real Decreto-ley 8/2020), a procedure to temporarily suspend a labour contract or cut working hours for economic, technical, organisational or production reasons derived from a force majeure may alleviate the effects in the labour market. Results from Arce (2020) and López Oller (2020) also show that the effects are different depending on the demographic group, the most affected groups being young and women, linked to their higher job instability. Instead, during the Great Recession the effects were very marked in concrete and masculinized sectors such as construction.

The crisis derived from COVID-19 pandemic also had a different impact at the regional level, for several reasons such as the different sectoral specialisation, the structural labour dynamics or the spread of COVID-19 infection. In addition, the closure measures were different across the Spanish regions. This paper focuses on Galicia since its employment distribution by sector may soften the COVID-19 effects in the short-run. In fact, the employment rate in Galicia was recovering more than the average rate in Spain in the third quarter of 2020. A possible reason to explain this recovery would be related to the combination of the difficulties to travel abroad and the relatively low incidence of COVID-19 in Galicia, becoming a safe tourist destination. At the same time, the regional government announced in September that Galicia has increased the employment rate every month from May 2020 (Europapress Galicia, 2020), in contrast with the predictions from Centro de Predicción Eonómica (CEPREDE) in March (Dones, 2020). Additionally, Galicia has a higher weight of employment in the primary sector recognised as essential activity during the lockdown and with permission to operate during the whole crisis.

However, the employment of the different demographic subgroups depending on their sex and age is not equally distributed across sectors, so the economic characteristics of the region are not equally protecting all groups. Thus, the effects of the COVID-19 pandemic can be different to some demographic groups depending on how concentrated they are in most affected sectors; in this case, services sectors such as hotels and restaurants, retail and so on or those sectors considered essential during the lockdown such as the primary or health sector.

For this reason, the aim of this paper is to analyse the effect of the COVID-19 pandemic on the employment changes of four demographic groups depending on their sex and age in Galicia. As we mentioned before, papers such as Arce (2020) and López Oller (2020) point out women and young workers as the most affected by the COVID-19 pandemic, for this reason we have selected women aged 16-29 years old, men aged 16-29 years old, women aged 30-64 years old and men aged 30-64. As our group of analysis, economic downturns may have effects on the retirement decision and for this reason we have not included workers aged 65 and over ${ }^{1}$.

In order to identify if the employment effects are specific from the particular characteristic of the COVID-19 pandemic or are the results of the structural problems of the Galician labour market, we analysed the evolution of the employment effects from 2008, comparing the Great Recession in 2008 with the first wave of the COVID-19 pandemic. To disentangle the structural responses from Galicia labour as "employment reserve" on the youth labour market from the sectoral particularities of each crisis, we apply Humphries (1988, rev. 2011) methodology. Authors such as Pena-Boquete (2014) found that during the Great Recession women were not used as the workforce reserve in Spain

\footnotetext{
${ }^{1}$ Retirement age in Spain is set in 67 years old, with some exceptions where workers can apply for retirement at 65 years old. ERTE seems to protect the group from 55 to 64 years old in this first wave keepin a behaviour similar to the 30-55 years old. We expect that the decision of early retirement could be important to understand the behaviour of this group but on later COVID-19 waves.
} 
and actually, gender segregation in the labour market worked sparing some female job losses. As we show in our paper, gender segregation was not alleviating employment losses for women this time.

To our knowledge, this paper is the first attempt to shed light on the employment losses due to COVID-19 for different demographic groups, disentangling losses due to buffer effects, usually related to the structural labour market issues, from segregation effects linked to the sectoral impact of each crisis, particularly, for a regional economy ${ }^{2}$. Consequently, we can identify to what extent sectoral versus structural policies need to be implemented. For instance, we attempt to approximate the effect of the ERTE subsidies in the first wave of the COVID-19 pandemic.

This paper is composed of four sections, starting with a descriptive part where we explain the particularities of the Galician region, which are the motivation to analyse this area, and the methodology. After the analysis we present the main results, where the ERTEs analysis is included, followed by the conclusions.

\section{Material and methods}

\subsection{Some general characteristics of the Galician labour market}

In this section, we provide some data based on the Labour Force Survey (LFS) on the Galician labour market for the variables that, as we mentioned in the introduction, make the Galicia region an interesting case study for analysing the effects of the COVID-19 pandemic (Table 1). For each variable, we analyse the data for all demographic groups so we can see if there are important changes between the Great Recession and COVID-19 pandemic. For this reason, we report data on 2008, 2009, 2019 and 2020. We provide data for Galicia and the rest of Spain to identify in which variables Galicia is performing differently from Spain. We also provide some data in the text to set these variables in a European context.

One of the variables that can contribute to a big and fast buffer effect is the share of employees with fixed-term contracts. The shorter temporary contracts are, the easier it is for employers to adjust employment to the production changes. Therefore, it facilitates hiring employees in the upswings and to fire them (or to not renew) in downturns. The Spanish labour market is characterised by an important weight of temporary contracts compared to the European Union 27 average (Table 1), where young men and women have values around $34 \%$ while in Spain it is even higher than $50 \%$. In both cases, women show higher values than men and also the young employees. The share of temporary contracts is even higher in the Galician region for these demographic groups. The buffer effect operating during the previous crises caused a decrease in the share of temporary groups from 2008 to 2009 for all demographic groups, continuing to decrease for several years. However, in 2019 young employees were showing levels of temporary contracts higher than in 2008, while employees aged 30 and more were showing levels of temporality lower than in 2008, both men and women.

The share of employees working in the public sector may act in the opposite direction than the share of temporary workers, i.e. the higher the share of public servants the smaller or slower the buffer effect, is particularly in the short term. On average, public servants tend to have more stable jobs than the private sector, and the public sector tends to cut jobs in later stages of the crises since this measure is extremely unpopular from a political point of view.

Galicia has a higher share of employees in the public sector compared to the rest of Spain (Table 1), with values of 2 to 5 percentage points higher depending on the demographic group. During the Great

\footnotetext{
2 Regional analyses are particularly important in Spain during de COVID-19 pandemic since neither the spread of the illness nor the measures implemented such as lockdowns or mobility restrictions have been uniform across regions.
} 
Recession the share of employees in the public sector has slightly decreased in all demographic groups except men older than 30 due to the high loss of employment suffered in others such construction. The share of women in the public sector is higher than for men both in Galicia and the rest of Spain, particularly for women older than 30 , where the difference with men from the same age is about 10 percentual points. However, this gap has been decreasing since the Great Recession in Galicia due to the decrease of women in the public sector by 3 percentage points, and also in the rest of Spain by the increase of men in the public sector by 2 points. Additionally, employees younger than 30 years old show low shares working in the public sector.

Table 1. Descriptive date on Galicia and rest of Spain labour market characteristics by gender and age

\begin{tabular}{|c|c|c|c|c|c|c|c|c|}
\hline & \multicolumn{4}{|c|}{ Galicia } & \multicolumn{4}{|c|}{ Rest of Spain } \\
\hline & \multicolumn{2}{|c|}{ Men } & \multicolumn{2}{|c|}{ Women } & \multicolumn{2}{|c|}{ Men } & \multicolumn{2}{|c|}{ Women } \\
\hline & $16-29$ & $30-64$ & $16-29$ & $30-64$ & $16-29$ & $30-64$ & $16-19$ & $30-64$ \\
\hline \multicolumn{9}{|c|}{ Share of employees with fixed-term contracts } \\
\hline 2008 & 52,6 & 21,6 & 55,5 & 26,0 & 48,7 & 21,4 & 48,7 & 25,3 \\
\hline 2009 & 50,7 & 18,0 & 48,8 & 23,7 & 43,1 & 18,2 & 45,0 & 21,9 \\
\hline 2019 & 63,1 & 19,8 & 59,8 & 23,5 & 54,0 & 20,3 & 56,4 & 21,9 \\
\hline 2020 & 54,6 & 17,5 & 59,1 & 22,1 & 49,7 & 18,0 & 53,8 & 20,5 \\
\hline \multicolumn{9}{|c|}{ Share of employees working on public sector } \\
\hline 2008 & 9,7 & 19,9 & 12,8 & 31,4 & 7,2 & 16,6 & 9,4 & 25,1 \\
\hline 2009 & 9,6 & 20,1 & 9,5 & 29,7 & 9,9 & 18,8 & 11,0 & 25,7 \\
\hline 2019 & 8,2 & 18,1 & 8,1 & 28,3 & 7,2 & 17,9 & 11,5 & 24,4 \\
\hline 2020 & 8,7 & 19,0 & 9,6 & 28,8 & 7,7 & 18,6 & 13,0 & 25,4 \\
\hline \multicolumn{9}{|c|}{ Share of workers on primary sector } \\
\hline 2008 & 6,0 & 9,0 & 2,0 & 8,6 & 3,6 & 5,1 & 1,9 & 2,4 \\
\hline 2009 & 5,5 & 9,6 & 2,8 & 8,4 & 4,8 & 5,2 & 1,6 & 2,3 \\
\hline 2019 & 7,3 & 7,2 & 1,9 & 5,1 & 5,8 & 5,5 & 1,4 & 2,0 \\
\hline 2020 & 8,1 & 7,9 & 0,7 & 4,9 & 5,7 & 5,5 & 1,6 & 1,8 \\
\hline
\end{tabular}

Source: LFS

During the lockdown, the Spanish government applied extraordinary measures, which were not affecting the so-called essential activities, including the primary sector as it is a fundamental element in the supply chain. On the other hand, sectors related to the hotels and restaurants have been deeply affected within this period.

So, the effects of COVID-19 on employment may be related to the sectoral structure. For instance, the number of employed has decreased in Galicia and the rest of Spain during the first wave of the pandemic, even though Galicia has been less affected. This could be partially due to the sectoral structure in Galicia, where agriculture covers around 6\% of total employment, especially high for men, while in Spain the weight is $4 \%$. The gap between men and women working in agriculture has been 
increasing over time, due to the important decrease of female workers in this sector, particularly in Galicia.

One of the most affected sectors by the COVID-19 pandemic was hotels and restaurants since on the one hand this sector has been closed by law, and on the other hand, even after the government allows the opening, the decrease on tourism arrivals due to the mobility restrictions and the fear of the illness really hit this sector. However, as Table 2 from the Hotel Occupancy Survey shows, the tourism sector has been less affected by the COVID-19 pandemic in Galicia relative to the rest of Spain. This table describes the variation rate from April to September (the two quarters where the impact of COVID-19 was more intense) compared to the same month in 2019, before the crisis. Even though the falls are huge relative to the same month of the previous year, Galicia was performing a bit better particularly in summer relative to the rest of Spain. As we mentioned before, the reason behind this trend could be that Galicia had a lower incidence than other regions in Spain, one of their main tourist attractions is open-air and with nature, and it depends more on national tourism (which makes arriving easier considering international mobility restrictions).

Table 2. Variation tax in overnight stays in hotel establishments per month in 2020

\begin{tabular}{lcc}
\hline & Galicia & Rest of Spain \\
\hline April & $-100 \%$ & $-100 \%$ \\
May & $-98 \%$ & $-99 \%$ \\
June & $-87 \%$ & $-95 \%$ \\
July & $-51 \%$ & $-74 \%$ \\
August & $-41 \%$ & $-65 \%$ \\
September & $-60 \%$ & $-79 \%$ \\
\hline
\end{tabular}

Source: Hotel Occupancy Survey.

Up to this point, we have shown the potential effects of sectoral structure focusing on two distinct sectors that are directly affected by the lockdown implementation. However, differences across demographic groups arise if industrial segregation is high taking all sectors into account. In order to show to what extent Galician workers are segregated, we apply the dissimilarity index by Duncan \& Duncan (1955), developed for occupational segregation but using employment by industries instead. This index can be interpreted as the proportion of workers from a particular group, such as women, that should be moved for example men, in order to have the same employment distribution. $I D_{t}=\frac{1}{2} \Sigma\left|m_{i t}-n_{i t}\right|$, being $m_{i t}$ and $n_{i t}$ the proportion of each of the groups per sector and year relative to the total employment of their own group.

In Figure 1, we show the dissimilarity index of different groups by sex and age per pair. We can observe dissimilarity indexes higher than $20 \%$ for all pairs of sub-groups, confirming that workers are concentrated in different sectors depending on their age and sex. The index was particularly high for young men versus young women, although it decreased by more than 10 percentage points. On the contrary, the dissimilarity index of men 16-29 versus men 30 years and older was increasing from 2012, meaning that employment structures of young and older men are becoming more and more different in time.

Taking into account the high level of sectoral segregation between demographic groups we should expect that the effects from the COVID-19 on employment will also be different. 


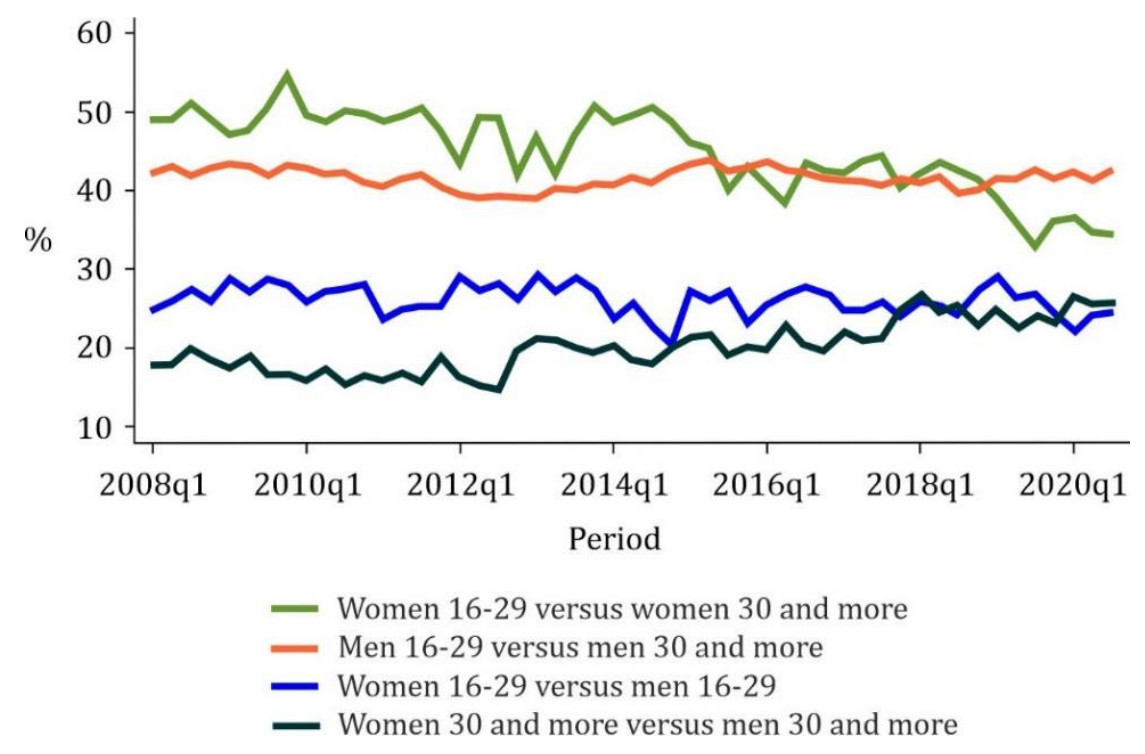

Figure 1. Duncan dissimilarity index by gender and age. Source: own elaboration based on data from the Spanish LF.

\subsection{Methodology}

In order to disentangle COVID-19 effects on employment between sectoral segregation effects and more structural effects such as the buffer effect, we apply the Humphries (1988) methodology. Based on this methodology, we decompose the dynamics of the employment of each demographic group into three different effects: growth, share, and interaction effects and shed light of differences between the Great Recession and the first wave of the crisis derived from COVID-19 pandemic ${ }^{3}$. In order to be clearer on the methodology explanation, we use the decomposition of youth employment as an example. The growth effect measures the effect of changes in total employment in each industry holding the share of young people in each industry constant. The share effect calculates the effect of changes in the share of young workers in each industry holding total employment in each industry constant. Finally, the interaction effect measures the interaction between changes in industrial employment and the share of young people.

The decomposition is represented by the following equation:

$$
\Delta N_{t}=\sum_{i}\left(T_{i t}-T_{i t-4}\right) p_{i t-4}+\sum_{i}\left(p_{i t}-p_{i t-4}\right) T_{i t-4}+\sum_{i}\left(p_{i t}-p_{i t-4}\right)\left(T_{i t}-T_{i t-4}\right)
$$

(growth effect) (share effect) (interactive effect)

where $N_{t}$ : youth employment in period $t$ (quarterly in this analysis), $p_{i t}$ : share of youth employment in the period $t, T_{i t}$ : total employment in the sector $i$ in the period $t$.

If the share effect shows positive values in boom periods and negative in crises, the analysed group (in this case youth) acts as a "buffer" labour force. Following this hypothesis, this group would be considered as a flexible reserve to be hired in upturns and fired in downturns. On the contrary, if the share effect is positive in downswings and negative during upswings, results could be consistent with the substitution hypothesis. This hypothesis proposes that the analysed group (for instance young

3 The Structural Decomposition Analysis (SDA) methodology applied by Carrascal (2017) and Duarte, Sarasa \& Serrano (2019) allows to calculate the changes on employment based on changes production and can be used to calculate some of the effects on this paper as well as predict some future changes on employment based on expected production changes. However, the absence of input-output tables for Galicia during each year on the period doesn't allow us to use this technique. Additionally, we will not be able do quarterly calculations important for estimating the effects during the COVID-19 first wave. 
workers) is considered a less expensive workforce, therefore, in recessions, they will substitute other groups as companies save costs.

Assuming $W_{i t}=\frac{T_{i t}}{\sum_{i} T_{i t}}$ calculates the share of each sector over the total employment, we can also break down the growth effect (GE) into three, as described below:

$$
\begin{aligned}
& \sum_{i}\left(W_{i t} T_{i t}-W_{i t-4} T_{i t-4}\right) p_{i t-4}=\sum_{i}\left(T_{i t}-T_{i t-4}\right) W_{i t-4} p_{i t-4}+\sum_{i}\left(W_{i t}-W_{i t-4}\right) T_{t-4} p_{i t-4}+\sum_{i}\left(W_{i t}-W_{i t-4}\right)\left(T_{i t}-T_{i t-4}\right) p_{i t-4} \\
& \text { (growth effect) (scale effect) (weight effect) (residual effect) }
\end{aligned}
$$

The scale effect describes the changes in the total number of workers, holding relative weights in sectors constant. The weight effect measures the changes derived from the relative weights of the sectors holding total employment constant. The residual effect measures the change derived from the interaction between the other two effects.

If the weight effect has positive values or around zero in recession, it could be consistent with the segregation effect acting as positive, i.e. this specific group (youth in the example) is concentrated in some sectors which were less affected by the crises. For instance, some authors support the idea that women are traditionally concentrated in relatively stable sectors in the economic cycle (Milkman, 1976), such as the services sector or the public sector.

In the next section, we will set out the results of the decomposition for each demographic groups separately, to identify which effect plays a more important role behind changes in employment.

This analysis is based on quarterly data from the LFS in the period between the first quarter of 2008 and the third quarter of 2020. Based on the employment records available in this survey we calculate total employment by age and sex disaggregated by industry at 2 digits for the Galician labour market. Since some of the sectors do not have many observations for some subgroups we have aggregated them in order to make them representative $e^{4}$. The detailed list of sectors is available in the appendix.

\section{Results}

The following figures show the results from the decomposition for the same demographic groups that we analysed in the previous sections in Galicia, comparing the Great Recession and the first wave of the crisis derived from COVID-19. In panel (a) of each figure, we decompose the employment change of each group and in panel (b) we further decompose the growth effect of the panel (a). Note that we are not keeping the same scale in the panels in order to fully appreciate the growth effect decomposition for each socioeconomic group. Additionally, the figures express the change of employment of each demographic group per quarter measured in thousands of workers, i.e. in absolute terms. However, the size of each group in the Galicia labour market is quite different meaning that the same value represents a different effect in relative terms (in particular, we compare younger and older groups). In order to have an idea of the size of each group, we indicate the average number of workers per group in 2019: women aged 16-29 represent about 56 thousand workers and men from the same age group are about 67 thousand, while women aged 30-64 years old are more than 460 thousand workers and men of the same age almost 500 thousand

We start the analysis with the young workers (16-29 years old) as in literature are considered they the more volatile group within the cycle dynamics. We can observe in Figure 2 that the changes in youth employment are mainly driven by the share effect, negative in the downturns, i.e during the Great Recession and the COVID-19 pandemic, and positive in the small recovery between crises. This

\footnotetext{
4 The aggregation was doing taking into account sectors with similar employment structures in order to arrive to a minimum number of observations per each sex-age-activity-time combination to arrive to a representative number. This minimum was set in 20 observations.
} 
strong behaviour of youth employment decreasing its share during the crises and increasing it during the recoveries confirms that young employees are being used as a "buffer" labour force as was mentioned in literature. This may be particularly important in the Galicia region since the share of young people with temporary contracts is very high in the European context.

The growth effect explains the rest of the fall in employment suffered by young workers both in the Great Recession and during the first quarter of the COVID-19 pandemic. At the same time, and as it will be for all groups analysed in this paper, the interaction effect is close to zero during the whole period.

In order to have a better understanding of the industrial changes behind the growth effect, we can further decompose it. Thus, this analysis shows us the first difference between the Great Recession and COVID-19 crises explaining the youth employment changes. Although the growth effect is mainly driven by the scale effect in both cases, the weight effect follows a positive evolution during the Great Recession and becomes negative in the COVID-19 pandemic.

Therefore, some sectors protected part of their young workers during the Great Recession and, however, in the current crisis derived from the COVID-19 pandemic, young workers are more concentrated in affected sectors, making the loss of employment relatively higher than for workers older than 30 years old.

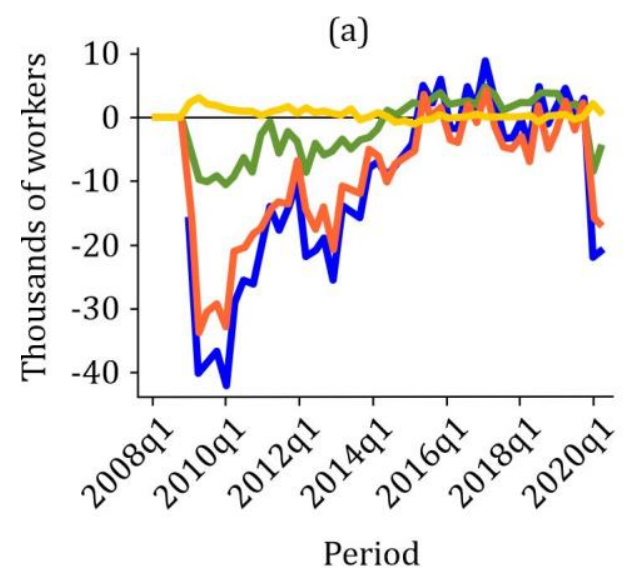

$\begin{array}{ll}\text { - Employment change } \quad-\text { Growth effect } \\ \text { - Interaction effect } & - \text { Share effect }\end{array}$



Period

- Growth effect - Scale effect

- Weight effect - Residual effect

Figure 2. Decomposition of changes in youth employment from 2008-2020. Source: own elaboration based on data from the Spanish LFS.

In order to delve deeper into the youth employment dynamics, we break down the decomposition analysis also by sex (Figure 3). The main difference in the decomposition between young women and men is that for the former, the employment changes are in a much lower quantity explained by the growth effect particularly during the Great Recession, i.e. the share effect is driven by most of the employment changes by women. We can understand the reasons behind the growth effect being relatively smaller for women than men when we further decompose it. Thus, the weight effect for women during the first phase of the Great Recession is remarkably high and positive, while negative for men in this period. As a result, the positive effect of the weight effect for women in that period compensates the negative scale effect given a relatively lower growth effect. This is consistent with the segregation hypothesis, as the first stage of the Great Recession mainly affected the construction sector, overrepresented by men. In the second stage, the crisis spread to other sectors, so the weight effect approaches zero. However, during the COVID-19 pandemic, female segregation does not seem to help them keep jobs and the weight effect shows negative values for both groups, being even higher for young female workers. 
Women

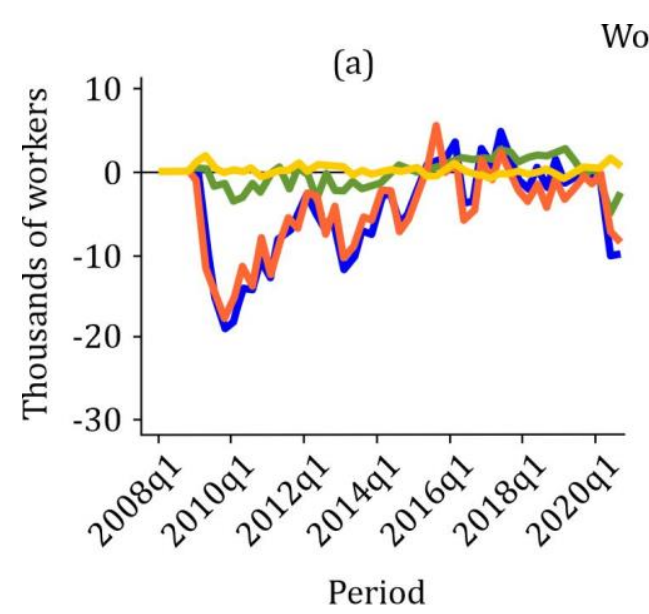

(b)

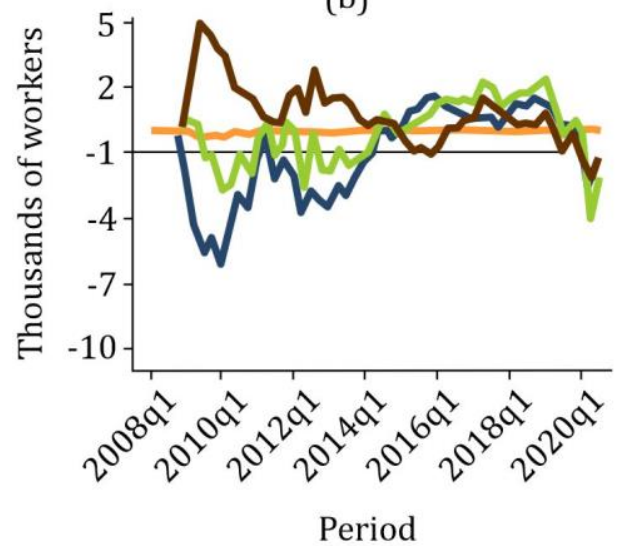

Men
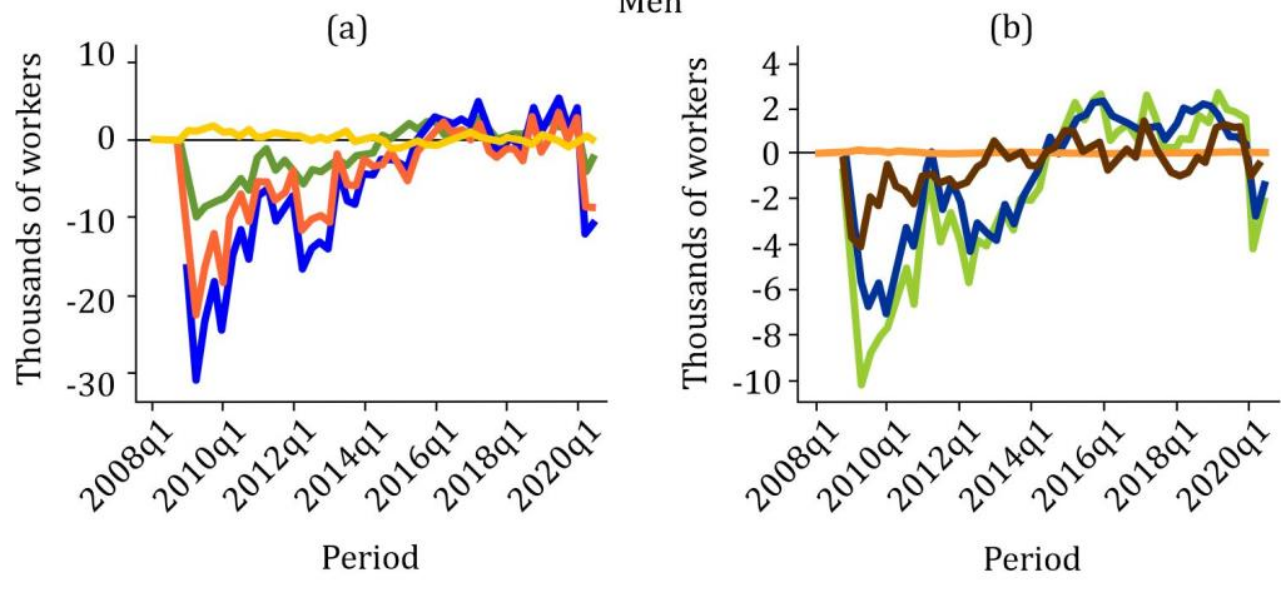

- Employment change - Growth effect

- Growth effect - Scale effect

- Weight effect - Residual effect

Figure 3. Decomposition of changes in employment for women and men aged 15-29 years old. Source: own elaboration based on data from the Spanish LFS.

Regarding the demographic group aged 30 and more (Figure 4), the growth effect mostly causes changes in employment, while the share effect works in the opposite direction in both crises. The evolution of this effect reflects the substitution hypothesis, i.e. since younger workers lost their jobs in a higher proportion than older ones, the share of people 30 and over -grows during the recession and substitutes younger workers. Workers older than 30 are the main group in the labour market and the one driving the total effect, as a result, the scale effect explains almost the whole pattern of the growth effect. Thus, to understand the changes better in this group the analysis by sex is important.

As in the previous figure, the share effect is positive in both groups in downturns (Great Recession and COVID-19 pandemic) and negative in recoveries, in line with the substitution hypothesis. The main changes in this group by sex (Figure 5) are within the decomposition of the growth effect. In fact, the weight effect is close to zero for the whole period for workers older than 30 is due to the opposite patterns in women and men. Women have, in general, positive values during the first crisis, following the segregation effect, while they are negative for men. Nevertheless, for the ongoing crisis, the situation is reversed, and the more affected sectors are where women (and youth as we saw before) are concentrated. 
(a)

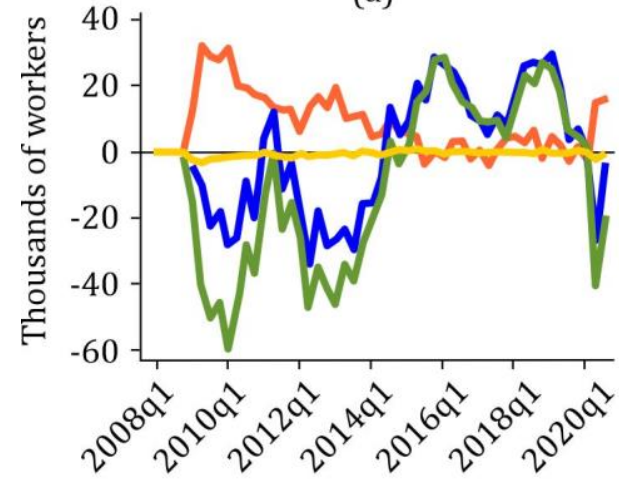

Period

- Employment change - Growth effect - Interaction effect $\quad$ - Share effect (b)

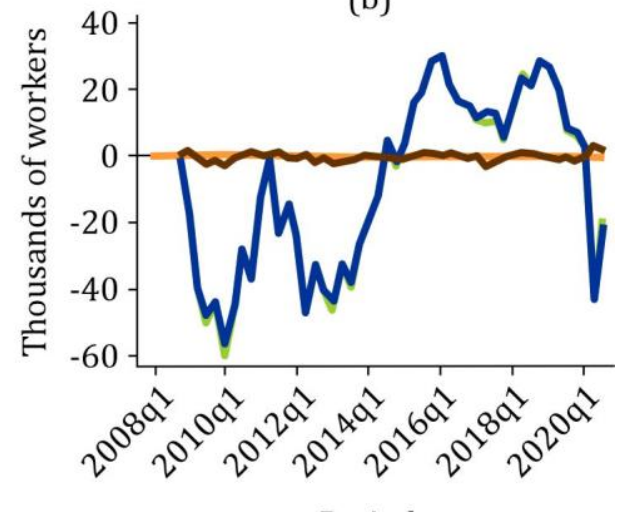

Period

$$
\begin{aligned}
& \text { - Growth effect } \quad \text { - Scale effect } \\
& \text { - Weight effect } \quad \text { - Residual effect }
\end{aligned}
$$

Figure 4. Decomposition of employment changes for workers age 30 to 64 from 2008-2020. Source: own elaboration based on data from the Spanish LFS.

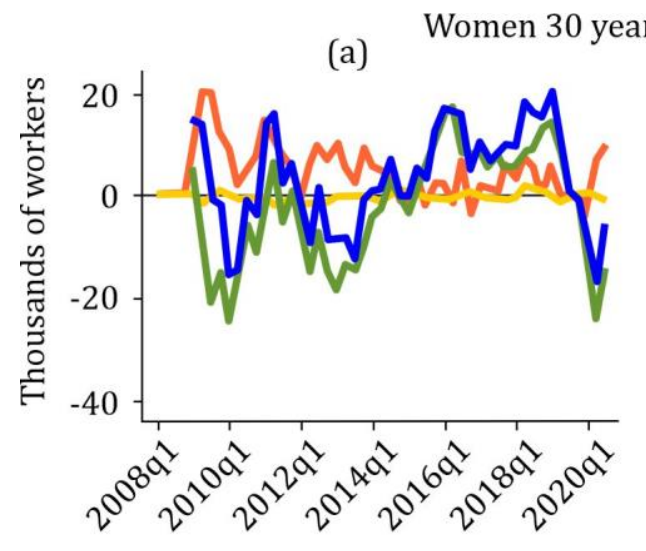

Period (b)



Period (a)

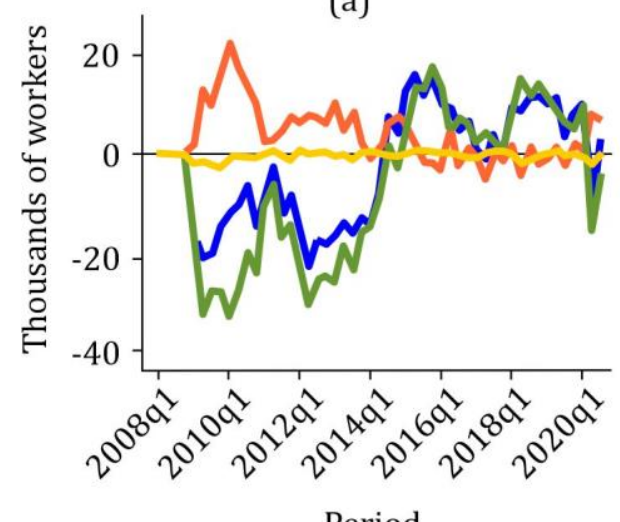

Period

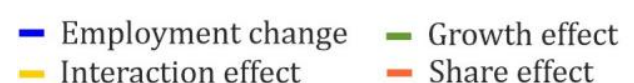

(b)

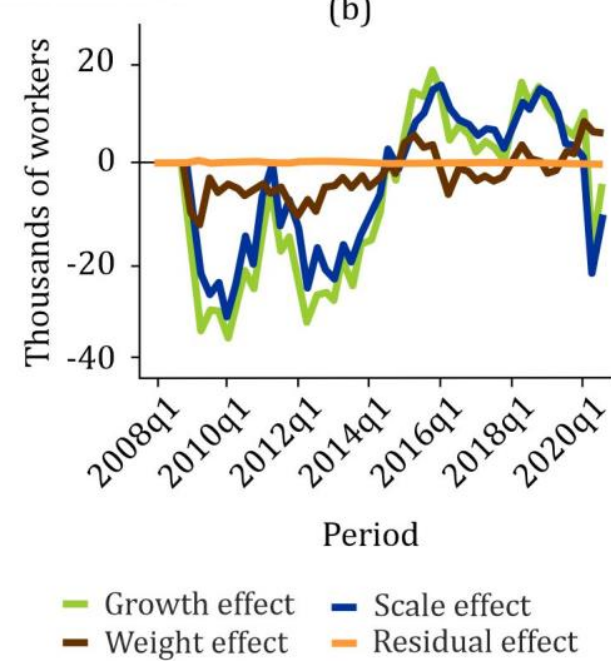

Figure 5. Decomposition of changes in employment for women and men aged 30 or more years old. Source: own elaboration based on data from the Spanish LFS 


\subsection{ERTE effect}

The Spanish government had implemented a system of employment protection at the beginning of the lockdown in March 2020, called Expediente de Regularización de Empleo Temporal (ERTE) ${ }^{5}$. Although this measure was already included in the Spanish Statute of Workers Rights, in 2020 it was modified in order to apply ERTE under force majeure circumstances. The ERTE is the mechanism which allows companies to temporarily suspend their activity, as a consequence of economic, technical, organizational or productive issues. Subsequently, it allows them to suspend contracts of workers or reduce their working hours. The valid period to apply for the ERTE has been extended until May 2021. During the ERTE, the worker will be covered by unemployment subsidies $(70 \%$ of their wages) but they do not appear as unemployed in the statistics. The number of ERTEs in the analysed period was decreasing over time, with a maximum in April of 165.038 in Galicia.

From a labour market point of view, these workers were classified and employed as they were receiving their "wages" but working 0 hours as could happen on sick leave or vacations ${ }^{6}$. If the economy fully recovers before the ERTE by force majeure finishes and all firms will be able to keep the employees, in the long-run the effects of the COVID-19 pandemic will be what we have seen in the previous section. It is expected that ERTE by force majeure has softened the loss of employment but it is not likely that all of them can be kept. Note that companies eligible for ERTEs subsidies should have reduced more than $75 \%$ of their production due to COVID-19. For this reason, we repeat the previous decomposition but not counting as employed everyone who reports 0 hours, i.e. also including, for instance, people on vacation or leave ${ }^{7}$. There are between $3 \%-7 \%$ people that work zero hours in each quarter, August being traditionally the one with higher shares due to the summer vacation. We are assuming that these shares are quite stable by quarters so they will not be relevant to the employment changes that we are calculating. However, in the second quarter of 2020 (when ERTE took place) the share of people reporting 0 hours is higher than $25 \%$ for all demographic groups. The numbers dropped to about $10 \%$ in the third quarter. Thus, results are consistent with shares in Table 3 once we remove the average share of people working 0 hours in previous months.

Thus, Figure 6 shows the decomposition for each demographic effect without accounting for the people working zero hours. This will mean that we are assuming that ERTE will all be unemployed, so it will be the worst scenario assuming the ERTE will not exist and will have zero effect. For all groups, the effect of the closure would be huge if the ERTEs had not taken place at all. The rest of the effects that we have mentioned in the previous sections and that explains the differences by groups will be maintained but with a lower magnitude. The recovery in the third quarter is mostly due to the endof ERTEs for several companies.

Young workers also present a marked decrease in the weight effect, showing that this crisis mostly affected sectors with an important presence of young people, e.g. the hotel and restaurant sector.

Results from this simulation represent the upper limit of employment loss, i.e. if all workers affected were directly unemployed.

\footnotetext{
5 Article 22 of the Boletín Oficial del Estado, Real Decreto-ley 8/2020, de 17 de marzo, de medidas urgentes extraordinarias para hacer frente al impacto económico y social del COVID-19.

${ }^{6}$ The effect will be completely different from the production point of view.

7 Our sample does not have all questions available in the Spanish LFS since we have sacrificed some questions in order to have an extra disaggregation by sectors in our request to the Instituto Galego de Estatística (IGE). For this reason, we are not able to identify the reasons why we are not able to identify the reason to work zero hours (less than the usual hours).

${ }^{8}$ Note that this proxy to evaluate ERTE by force majeure is taking into account any other policy that supposes to report zero hours, such as traditional ERTEs, regulations on sick leave. However, results show that any policy change seems to cause such a big effect as the ERTE by force majeure.
} 
Table 3. Share of ERTEs force majeure over social security affiliates in Galicia. April - September 2020

\begin{tabular}{lc}
\hline & $\begin{array}{c}\% \text { ERTEs force majeure over } \\
\text { social security affiliates }\end{array}$ \\
\hline April & $15,4 \%$ \\
May & $12,1 \%$ \\
June & $6,5 \%$ \\
July & $3,5 \%$ \\
August & $2,2 \%$ \\
September & $1,8 \%$ \\
\hline
\end{tabular}

Source: Share of ERTEs force majeure over social security affiliates in Galicia. April-September 2020.

(a)

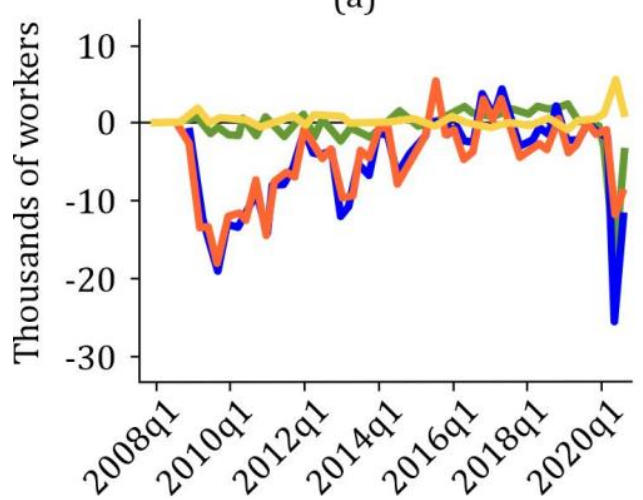

Period

(a)

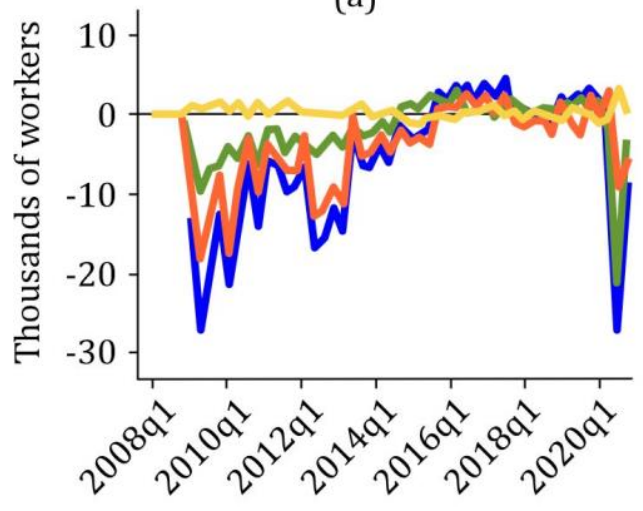

Period

- Employment change - Growth effect - Interaction effect - Share effect (b)

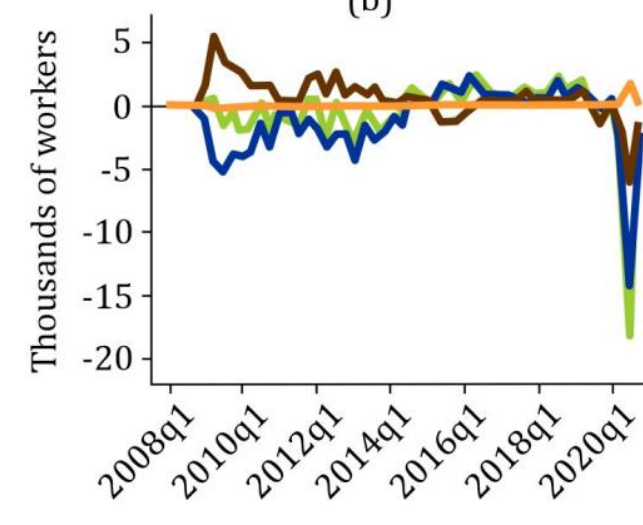

Period

Figure 6. Decomposition of changes in employment by sex and age, adjusted by ERTE policy. Source: own elaboration based on data from the Spanish LFS. 
(a)

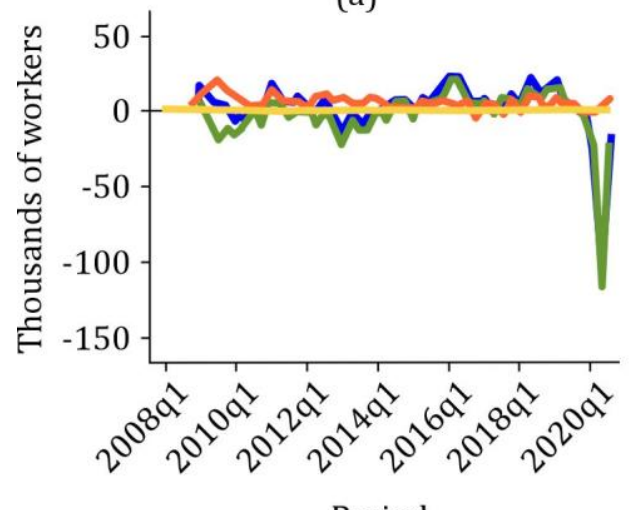

Period (b)

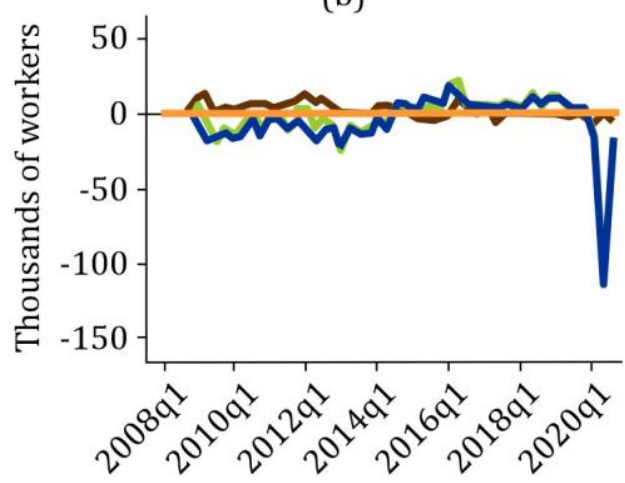

Period

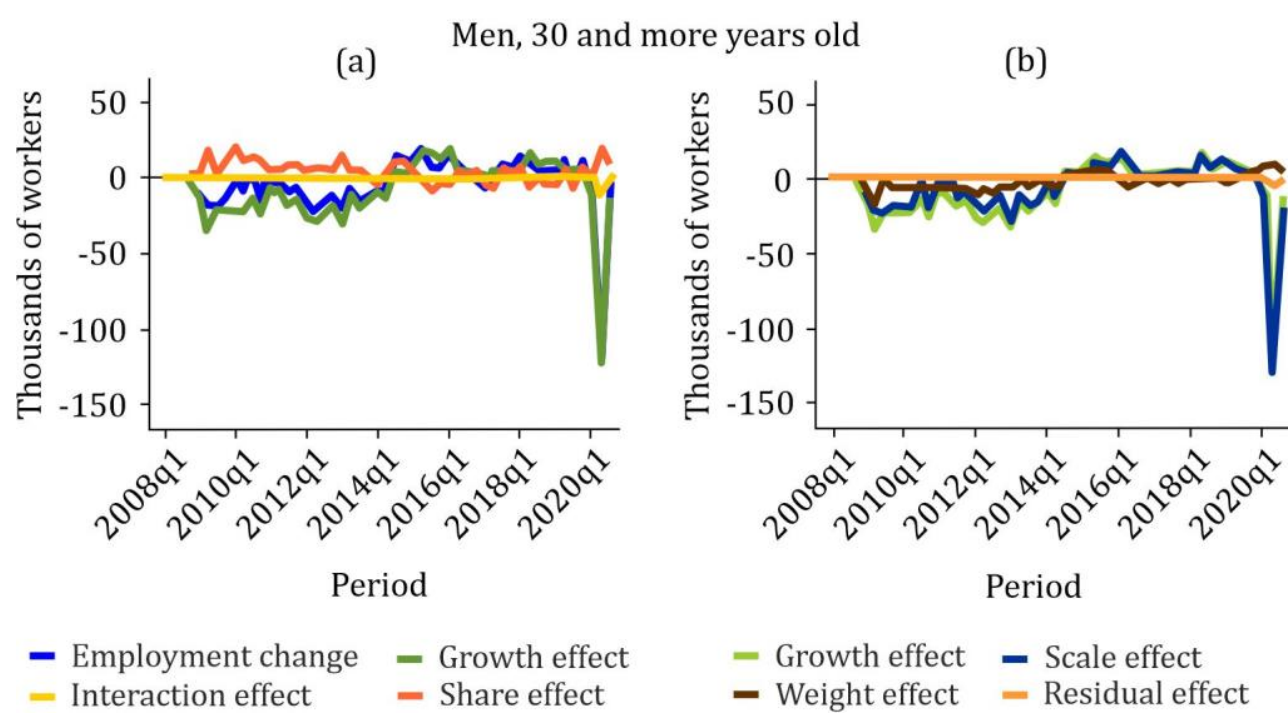

Figure 6 (continuation). Decomposition of changes in employment by sex and age, adjusted by ERTE policy. Source: own elaboration based on data from the Spanish LFS.

\section{Conclusions}

Reports from the Banco de España or other institutions such as the Instituto de la Juventud (INJUVE), a public institution that promotes actions to benefit young people (Arce, 2020; López Oller, 2020) show that youth and female employment has been more affected by the COVID-19 pandemic in Spain. In this paper, we attempt to disentangle what is behind these employment changes: industrial segregation, workers used as employment reserve, substitution effect and so on in order to shed some light on the most appropriate policies.

Results of the decomposition show that young workers (16-29 years old) have been used as a "buffer" in the Galician economy: firing them during downturns and hiring them during upturns, and the COVID-19 crisis has not been an exception. This means that using a sectoral policy to reduce the employment effects of COVID-19 on youth groups may alleviate the effects but not solve the problem. One of the reasons behind being able to use youth employment as an employment reserve may be the high share of young workers holding temporary jobs compared to the European average. In 2019, this share of youth workers was close to $60 \%$ in Galicia, almost double that of the European Union $27^{9}$. In fact, it seems that ERTE protected less youth employment than jobs of workers older than 30 years old

${ }^{9}$ For EU 27 the age range is from 15 to 29 years old. 
since their contracts were not renewed at the end of February or beginning of March, i.e. before the ERTE took place.

This buffer effect has traditionally operated in all recessions, particularly on younger workers and it is part of the structural problems of the Spanish labour market linked to the over dimension of temporary contracts. García-Pérez, Marinescu \& Vall Castello (2019) show that fixed-term contracts are not acting as stepping-stones for a better future career for young workers in the Spanish labour market and the long-term impact may be negative. Thus, policies to recover employment should also take this into account, as the Organisation for Economic Co-operation and Development (OECD) points out the COVID-19 pandemic offers a great window of opportunity for policy makers to integrate a stronger focus on youth and future generations as well as gender mainstreaming in sectoral policies. Youth and intergenerational considerations, as well as those of gender, should also be integrated into governments' strategies for the economic response to COVID-19, as recommended by the OECD (2020).

Effects on the employment of using youth as an employment reserve were compensating for segregation effects during the Great Recession, particularly for women, i.e. as the first stage of the Great Recession mainly affected the construction sector, overrepresented by men, women lost fewer jobs. This sectoral effect works in the opposite way during the COVID-19, the more affected sectors are overrepresented by women and young workers. The sectors that showed the most significant falls in activity since the entry into force of the state of alarm (Banco de España, 2020) were the hospitality, artistic, recreational and entertainment activities, and other services. This group of sectors has a higher proportion of young workers and, particularly, women.

Thus, sectoral policies can help to recover some of the lost jobs, however given the uncertainty surrounding the duration of the health crisis, it is feasible that only sectoral policies will not allow for the recovery of all youth employment. Moreover, it also represents an opportunity to foster emerging sectors that ensure sustainable and equitable future growth. The International Labour Organization (ILO, 2020) considers that young working people perform better than adults in technology-rich employment and would allow them to adapt more easily to more technologically intensive work even if they had not been developing it in the previous job.

In fact, COVID-19 has accelerated the process of digitization and transformation of some work tasks, increasing job creation through digital platforms. In fact, the weight in the platform economy has considerably grown during the pandemic, and young men and women have moved towards this type of work. However, a deeper analysis of this new economy should be carried out in order to understand their potential as a future employment source from the economic point of view. The occupational segregation analysis should be considered to include the digitalization and automatization process (Blau, Simpson \& Anderson, 1998; Fuchs, 1988) as well as new legislative forms (these new types of jobs have been highlighted by lack of protection suffered, especially young workers).

Instead, the demographic group aged 30 and more is behaving according to the substitution hypothesis, i.e. since younger workers lost their jobs in a higher proportion than older, the share of people older than 30 is growing during the recessions and substituted younger workers. This is particularly true during the COVID-19 pandemic, since, as we mentioned before, the ERTES protected older rather than young workers to a greater extent, and some of the young workers were already unemployed when the ERTE took place. However, within the group of 30 years old, there are also important differences between men and women. Sectoral segregation was used to protect female employment in the downturn since they were more concentrated in service sectors which then became more volatile during the business cycles. Nevertheless, for the ongoing crisis, the situation is reversed, and the sectors most affected by the COVID-19 are where women (and youth as we saw previously) are concentrated.

When we assumed that the ERTE never took place and everybody working 0 hours was, in fact, unemployed, the effect of the closure would be huge for all demographic groups, particularly in the second quarter. The rest of the effects that we have just described for each group will be the same although with a relatively lower magnitude, compared with the huge loss of employment by ERTE. 
Thus, ERTEs subsidies seem to be useful to soften the employment loss (and consequently the income losses) of Galician workers during the first wave of the COVID-19 pandemic.

\section{Appendix}

\begin{tabular}{|c|c|}
\hline Aggregation & Clasificación Nacional de Actividades Económicas (CNAE) 2009 \\
\hline Primary & $\begin{array}{l}01 \text { Crop and animal production, hunting and related service activities. } \\
02 \text { Forestry and logging. } \\
03 \text { Fishing and aquaculture. }\end{array}$ \\
\hline Extractive industries & $\begin{array}{l}05 \text { Mining of coal and lignite. } \\
06 \text { Extraction of crude petroleum and natural gas. } \\
07 \text { Mining of metal ores. } \\
08 \text { Other mining and quarrying. } \\
09 \text { Mining support service activities. }\end{array}$ \\
\hline $\begin{array}{l}\text { Food, beverage and tobacco } \\
\text { industry }\end{array}$ & $\begin{array}{l}10 \text { Manufacture of food products. } \\
11 \text { Manufacture of beverages. } \\
12 \text { Manufacture of tobacco products. }\end{array}$ \\
\hline $\begin{array}{l}\text { Textile, clothing and footwear } \\
\text { industry }\end{array}$ & $\begin{array}{l}13 \text { Manufacture of textiles. } \\
14 \text { Manufacture of wearing apparel. } \\
15 \text { Manufacture of leather and footwear. }\end{array}$ \\
\hline Wood, cork and paper industry & $\begin{array}{l}16 \text { Manufacture of products of wood, cork, straw and plaiting materials. } \\
17 \text { Manufacture of paper and paperboard. }\end{array}$ \\
\hline $\begin{array}{l}\text { Petroleum, chemical and } \\
\text { pharmaceutical products }\end{array}$ & $\begin{array}{l}19 \text { Manufacture of coke and refined petroleum products. } \\
20 \text { Manufacture of chemicals and chemical products. } \\
21 \text { Manufacture of pharmaceutical preparations. } \\
22 \text { Manufacture of rubber and plastic products. } \\
23 \text { Manufacture of other non-metallic mineral products. }\end{array}$ \\
\hline Metallurgy and metal products & $\begin{array}{l}24 \text { Manufacture of basic iron and steel and of ferro-alloys. } \\
25 \text { Manufacture of fabricated metal products, except machinery and } \\
\text { equipment. }\end{array}$ \\
\hline Machinery and equipment & $\begin{array}{l}26 \text { Manufacture of computer, electronic and optical products. } \\
27 \text { Manufacture of electrical equipment. } \\
28 \text { Manufacture of machinery and equipment n.e.c. }\end{array}$ \\
\hline $\begin{array}{l}\text { Motor vehicles and transport } \\
\text { equipment }\end{array}$ & $\begin{array}{l}29 \text { Manufacture of motor vehicles, trailers and semi-trailers. } \\
30 \text { Manufacture of other transport equipment. } \\
33 \text { Repair and installation of machinery and equipment. }\end{array}$ \\
\hline Furniture and others & $\begin{array}{l}31 \text { Manufacture of furniture. } \\
32 \text { Other manufacturing. }\end{array}$ \\
\hline Energy, water and recycling & $\begin{array}{l}35 \text { Electricity, gas, steam and air conditioning supply. } \\
36 \text { Collection, purification and distribution of water. } \\
37 \text { Water collection, treatment and supply. } \\
38 \text { Waste collection, treatment and disposal activities; materials recovery. } \\
39 \text { Remediation activities and other waste management services. }\end{array}$ \\
\hline
\end{tabular}




\begin{tabular}{|c|c|}
\hline Aggregation & Clasificación Nacional de Actividades Económicas (CNAE) 2009 \\
\hline Construction & $\begin{array}{l}41 \text { Construction of buildings. } \\
42 \text { Civil engineering. } \\
43 \text { Specialised construction activities. }\end{array}$ \\
\hline Sale and repair of motor vehicles & 45 Wholesale and retail trade and repair of motor vehicles and motorcycles. \\
\hline Wholesale trade & 46 Wholesale trade, except of motor vehicles and motorcycles. \\
\hline Retail trade & 47 Retail trade, except of motor vehicles and motorcycles. \\
\hline Transport & $\begin{array}{l}49 \text { Land transport and transport via pipelines. } \\
50 \text { Sea and coastal water transport. } \\
51 \text { Air transport. }\end{array}$ \\
\hline Post & $\begin{array}{l}52 \text { Warehousing and support activities for transportation. } \\
53 \text { Postal and courier activities. }\end{array}$ \\
\hline Accommodation services & 55 Accommodation services. \\
\hline Food and beverage services & 56 Food and beverage service activities. \\
\hline Editing and information services & $\begin{array}{l}18 \text { Printing and reproduction of recorded media. } \\
58 \text { Publishing activities. } \\
59 \text { Motion picture, video and television programme production, sound } \\
\text { recording and music publishing activities. } \\
60 \text { Programming and broadcasting activities. } \\
61 \text { Telecommunications. } \\
63 \text { Information service activities. }\end{array}$ \\
\hline Computing & 62 Computer programming, consultancy and related activities. \\
\hline Financial and insurance services & $\begin{array}{l}64 \text { Financial service activities, except insurance and pension funding. } \\
65 \text { Insurance, reinsurance and pension funding, except compulsory social } \\
\text { security. } \\
66 \text { Activities auxiliary to financial services and insurance activities. }\end{array}$ \\
\hline Real estate services & $\begin{array}{l}68 \text { Real estate activities. } \\
77 \text { Rental and leasing activities. }\end{array}$ \\
\hline Business services & $\begin{array}{l}69 \text { Legal and accounting activities. } \\
70 \text { Activities of head offices; management consultancy activities. } \\
82 \text { Office administrative and support activities. }\end{array}$ \\
\hline Architectural services & 71 Architectural and engineering activities; technical testing and analysis. \\
\hline Research and market survey & $\begin{array}{l}72 \text { Scientific research and development. } \\
73 \text { Advertising and market research. } \\
74 \text { Other professional, scientific and technical activities. }\end{array}$ \\
\hline Veterinary activities & 75 Veterinary activities. \\
\hline Other professional activities & $\begin{array}{l}78 \text { Employment activities. } \\
79 \text { Travel agency, tour operator and other reservation service and related } \\
\text { activities. } \\
80 \text { Security and investigation activities. } \\
81 \text { Services to buildings and landscape activities. }\end{array}$ \\
\hline
\end{tabular}




\begin{tabular}{ll}
\hline Aggregation & Clasificación Nacional de Actividades Económicas (CNAE) 2009 \\
\hline Public administration & 84 Public administration and defence; compulsory social security. \\
Education & 85 Education. \\
Health activities & 86 Human health activities. \\
Social services & 87 Residential care activities. \\
& 88 Social work activities without accommodation. \\
& 90 Creative, arts and entertainment activities. \\
Cultural and artistic activities & 91 Libraries, archives, museums and other cultural activities. \\
& 92 Gambling and betting activities. \\
& 93 Sports activities and amusement and recreation activities. \\
& 94 Activities of membership organisations. \\
& 95 Repair of computers and personal and household goods. \\
& 96 Other personal service activities. \\
& 97 Activities of households as employers of domestic personnel. \\
& 98 Undifferentiated goods-producing activities of private households for \\
own use. & 99 Activities of extraterritorial organisations and bodies. \\
\hline
\end{tabular}

\section{References}

Arce, 0. (2020). El impacto de la crisis del COVID-19 sobre el empleo de los jóvenes y las mujeres. Madrid: Banco de España. Retrieved from: https://www.bde.es/f/webbde/GAP/Secciones/SalaPrensa/IntervencionesPublicas/DirectoresGenerales/ec onomia/Arc/arce080720.pdf

Banco de España. (2020). Escenarios macroeconómicos de referencia para la economía española tras el Covid-19. Boletín Económico, 2/2020, 1-35. Madrid: Banco de España.

Retrieved from: https://www.bde.es/f/webbde/GAP/Secciones/SalaPrensa/COVID-19/be2002-art1.pdf

Blau, F. D., Simpson, P., \& Anderson, D. (1998). Continuing progress? Trends in occupational segregation in the United States over the 1970s and 1980s. Feminist Economics, 4(3), 29-71. DOI: https://doi.org/10.1080/135457098338301

Carrascal, A. (2017). Drivers of change in the European youth employment: A comparative structural decomposition analysis. Economic Systems Research, 29(4), 463-485. DOI: https://doi.org/10.1080/09535314.2017.1316708

Dones, M. (2020). Impacto regional del estado de alarma. Notas CEPREDE, 23 de marzo de 2020. Madrid: Centro de Predicción Económica. Retrieved from:

https://www.ceprede.es/informes/notas ceprede/Nota\%20CEPREDE\%20CORONAVIRUS\%20REGIONAL.pd f?utm source=CEPREDE+Periodistas $+\mathrm{y}+$ Usuarios\&utm campaign=45c414fc56EMAIL CAMPAIGN 2020032310 42\&utm medium=email\&utm term=0 7af9033c41-45c414fc56264611797

Duarte, R., Sarasa, C., \& Serrano, M. (2019). Structural change and female participation in recent economic growth: A multisectoral analysis for the Spanish economy structural change and female participation in recent economy. Economic Systems Research, 31(4), 574-593. DOI: https://doi.org/10.1080/09535314.2019.1589425

Duncan, O. D., \& Duncan, B. (1955). A methodological analysis of segregation indexes. American Sociological Review, 20(2), 210-217. DOI: https://doi.org/10.2307/2088328

Europapress Galicia. (02/09/2020). Galicia resiste la crisis generada por la Covid-19 con la creación de empleo por cuarto mes consecutivo. Retrieved from: https://www.galiciapress.es/texto-diario/mostrar/2074205/xuntaresalta-galicia-resiste-crisis-covid-19-creacion-empleo-cuarto-mes-seguido 
Felgueroso, F., de la Fuente, A., Boscá, J. E., Doménech, R., Ferri, J., García Pérez, J. I., Jiménez, S., Rodríguez, D., \& Viola, A. (2020). Aspectos económicos de la crisis del Covid-19. Boletín de seguimiento no 2. Estudios sobre la Economía Española-2020/14. Retrieved from:http://documentos.fedea.net/pubs/eee/eee2020-14.pdf

Fuchs, V. R. (1975). A note on sex segregation in professional occupations. In NBER, Explorations in economic cesearch, volume 2, number 1 (pp. 105-111). Cambridge, MA: National Bureau of Economic Research. Retrieved from: https://www.nber.org/system/files/chapters/c7405/c7405.pdf

García-Pérez, J. I., Marinescu, I., \& Vall Castello, J. (2019). Can fixed-term contracts put low skilled youth on a better career path? Evidence from Spain. The Economic Journal, 129(620), 1693-1730. DOI: http://doi.org/10.1111/ecoj.12621

Humphries, J. (1988, rev. 2011). Women's employment in restructuring America: The changing experience of women in three recessions. In J. Rubery (Ed.), Women and recession (Routledge Revivals) (chapter 1). London, UK: Routledge.

Retrieved from: https://www.routledge.com/Women-and-Recession/Rubery/p/book/9780415609234

ILO. (2020). Preventing exclusion from the labour market: tackling the COVID-19 youth employment crisis. Geneva, Switzerland: International Labour Organization. Retrieved from: https://www.ilo.org/wcmsp5/groups/public/---ed emp/documents/publication/wcms 746031.pdf

INE. (several years). Labour Force Survey (LFS). Madrid: Instituto Nacional de Estadística.

López Oller, J. (2020). Juventud en riesgo: análisis de las consecuencias socioeconómicas de la COVID-19 sobre la población joven en España. Informe de urgencia/1. Madrid: Instituto de la Juventud (INJUVE). Retrieved from: http://www.injuve.es/sites/default/files/adjuntos/2020/06/estudio_consecuencias_economicas_covid19_e $\underline{\text { n la juventud.pdf }}$

Milkman, R. (1976). Women's work and economic crisis: Some lessons of the Great Depression. Review of Radical Political Economics, 8(1), 73-97. DOI: https://doi.org/10.1177/048661347600800107

OECD. (2020). OECD policy responses to coronavirus (COVID-19). Youth and COVID-19: Response, recovery and resilience. Paris, France: Organisation for Economic Co-operation and Development. Retrieved from: https://www.oecd.org/coronavirus/policy-responses/youth-and-covid-19-response-recovery-andresilience-c40e61c6/

Pena-Boquete, Y. (2014). Have the economic crises reduced the gender gap on the Spanish labour market? Revue de l'OFCE, 2014/2(133), 277-302. DOI: https://doi.org/10.3917/reof.133.0277

Real Decreto-ley 8/2020, de 17 de marzo, de medidas urgentes extraordinarias para hacer frente al impacto económico y social del COVID-19. Legislación consolidada. Jefatura del Estado. Boletín Oficial del Estado, 73, de 18 de marzo de 2020. Referencia: BOE-A-2020-3824.

Retrieved from: https://www.boe.es/diario boe/txt.php?id=BOE-A-2020-3824 